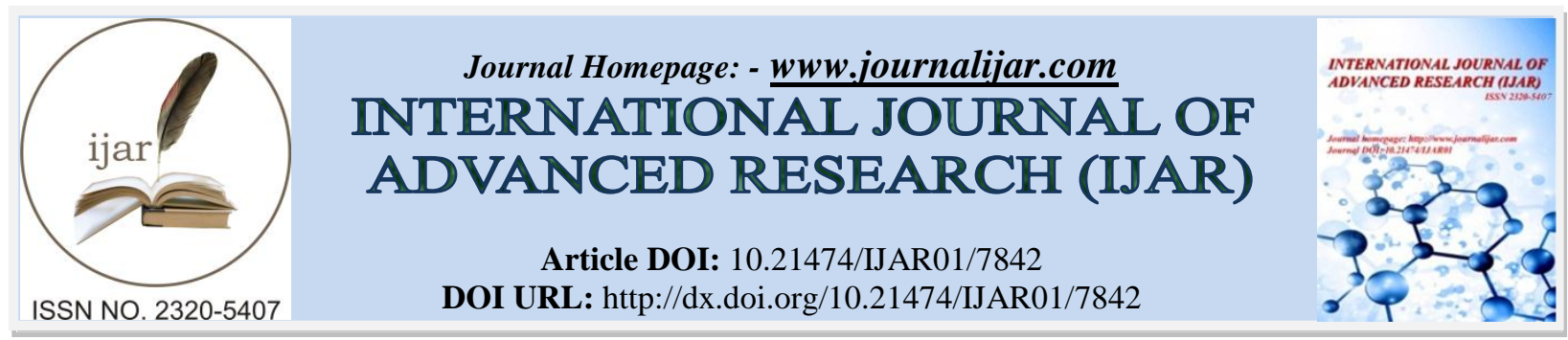

RESEARCH ARTICLE

\title{
A STUDY ON VARIOUS INNOVATIVE PRACTICES INCORPORATED BY THE FRONT OFFICE DEPARTMENT \& MEASURING THEIR IMPACT ON GUEST SATISFACTION WITH RESPECT TO THE WESTIN GURGAON, NEW DELHI HOTEL.
}

Mr. Akshay Nain, Mr. Abhimanyu Awasthi and Dr. Kunal Seth.

Amity School of Hospitality, Amity University Haryana, Pachgaon, Manesar, Gurugram, Haryana, India.

\section{Manuscript Info}

Manuscript History

Received: 8 August 2018

Final Accepted: 10 September 2018

Published: October 2018

\section{Keywords:}

innovative practices, front office department, guest satisfaction, retention, loyalty

\section{Abstract}

The research paper focuses on finding the various innovative practices incorporated by the front office department of The Westin Gurgaon, New Delhi hotel and measuring their impact on guest satisfaction comprehensively. Based on the findings, it is found that there is reasonable positive \& healthy impact of various innovative practices incorporated by the front office department of The Westin Gurgaon, New Delhi hotel on guest satisfaction, retention \& loyalty.

Copy Right, IJAR, 2018,. All rights reserved.

\section{Introduction:-}

The Westin Gurgaon, New Delhi, is a sprawling 313 room five star hotel strategically located in the heart of millennium city - Gurgaon (recently, Gurgaon has been declared as metropolitan city). This hotel is located just 25 minutes from the New Delhi Indira Gandhi International Airport. The hotel brings a fresh, new lifestyle experience to the city, surrounded by upscale shopping malls, entertainment hubs, multiplexes and commercial offices making it an ideal choice for both business and leisure. Its distinct architectural design reflects clutter free spaces laying strong emphasis on openness and natural lighting. There are large numbers of five star hotels in Gurgaon \& competition among them is severe. Since the competition is cut throat, it becomes very important for every hotel to provide exemplary \& exclusive services to each \& every guest in order to provide utmost satisfaction which eventually leads to guest retention \& loyalty. The front office department is the face \& mirror image of every hotel $\&$ guests interact maximum with hotel's front office staff only. The level of guest's satisfaction undoubtedly depends a lot on services \& practices offered \& followed by front office department respectively.

\section{Objectives}

1. To study various innovative practices incorporated by front office department of The Westin Gurgaon, New Delhi Hotel.

2. To measure the impact of various innovative practices incorporated by front office department on guest satisfaction at The Westin Gurgaon, New Delhi Hotel.

\section{Literature Review}

Judy Siguaw, 1999 discusses about implementing outstanding or best practices to improve operations. When effective practices were implemented in the front office especially check-in and check-out, there was an increase in the guest and employee satisfaction, along with considerable profit improvements. The practices include sharing with employees the savings from revised work practices, particularly those that prescribe standard times for each activity. 
Tom Baum, 2001, the researcher emphasizes on the changing functions of the front office operations. It includes the role of the personnel, multi skilling, balancing between technologic advancement and delivering of quality customer care, expectation of faster response to more complex methods of communication, bench marks for various services. It gives an insight into the various changes in the front office practices and how technology is working as an enabling force and not replacing the traditional roles. It also addresses the importance of educating and training the employees for better performance.

Riza Munira Binti Shamsudin, 2012, the research states that guest satisfaction is a differentiator and a critical success factor for the hotel. It shows the results of the study of performance management of Front Office department and guest satisfaction. The hotel performance is impacted because of the attitude and the motivational levels of the employees.

Asad Mohsin, 2010, the study aims to assess the service quality perception of customers of the hotels and helps the management to identify areas that need attention to meet and exceed customer expectations. The results indicate that there is significant difference between expectations of the guests and the actual experiences.

Melia, 2010, the study suggests the satisfaction of the guest as important success factor for the hotel's survival. Guest satisfaction plays important role and it helps hotel to improve its standards as well as imparts knowledge about the competitors.

Alin Sriyam, 2010, the study suggest that if the front office staff is efficient and cooperative it will lead to customer satisfaction in the hotel.

Kong Hai Yan, 2006, the study focuses on the front office staff in the four and five star hotels in China. The findings suggest that work in this department of hotel is challenging, demanding and communication is an important skill for the staff. It also says that high-quality human resources are lacking in the hospitality sector and emphasizes on professional development and training in order to improve the skills of staff in the front office.

\section{Research Methodology:-}

The research methodology is based on both primary \& secondary data. The primary data was collected based on questionnaire comprising of 50 questions related to various front office practices \& their impact \& effect on guest satisfaction. The questionnaire had two degrees of satisfaction - like \& dislike. The questionnaire was filled by 100 guests between $05^{\text {th }}$ to $15^{\text {th }}$ September 2018. The secondary data was collected through various research papers of reputed journals, newspapers, magazines \& internet.

\section{Various innovative practices incorporated by front office department of The Westin Gurgaon, New Delhi Hotel}

Based on the feedback received from guests visiting \& staying in this hotel through questionnaire, this hotel's front office department has developed \& incorporated many innovative practices. This hotel's front office department provides in-room check-in to each \& every guest. All the check-in formalities are completed in the guest room by the front office staff which not only saves guest's time but also avoids ques at the reception \& lobby. This hotel's front office department will very soon place a self check-in \& self check-out kiosk for all the hotel guest's. This concept of self check-in \& self check-out kiosk is existing in very limited hotels worldwide. This hotel's front office department uses digital placards for locating its guests at airports. The hotel's front office department sends chauffer details well in advance to hotel guests who wish to avail hotel transport facility which eventually helps in locating each other smoothly at airports. All the hotel guests are welcomed with aarti, tika, cold towels \& flower garlands everyday at main entrance. All the hotel limousines are equipped with one small minibar with the purpose of providing refreshments to all the hotel guests during travel journey on complimentary basis. The front office department provides extensive training to its staff members at regular intervals to meet all the required \& desired competencies. The front office department has equipped itself with Guest Satisfaction Tracking System which itself is very unique \& innovative \& helps in identifying the facilities that are most liked by hotel guests \& eventually leads to guest satisfaction, guest retention \& loyalty respectively. All the front office staff are asked to be aware of local tourist \& sightseeing spots in order to recommend the same to hotel guests as \& when required. The hotel front office department conducts recreational activities such as indoor games like carom board, chess, table-tennis, squash, badminton, ludo, cards etc. for hotel guests on every sunday afternoon. The kids who are accompanying 
their parents are asked by the front office staff to mention their favourite food \& beverage item at the time of checkin \& same food \& beverage item is served to them after shortwhile through room service \& that too on complimentary basis. All the hotel guests are served welcome drink and/or fresh fruits during check-in without fail. The guest's who complete minimum twenty five visits or stays are offered one time complimentary dinner to celebrate their relationship with the hotel on every visit or stay henceforth. All the above mentioned ideas are purely \& solely invented, discovered \& implemented by hotel's front office department.

\section{Impact of various innovative practices incorporated by front office department on guest satisfaction at The Westin Gurgaon, New Delhi Hotel}

Majority of guests were fully satisfied with the various innovative practices \& services offered to them by front office department of the hotel. Most of the guests mentioned that they thoroughly enjoy their stay with the hotel every time they visit the hotel. 96 percent of guests mentioned that the hotel front office staff is highly motivated, trained, courteous, competent \& responsible. 98 percent of guests like the concept of in-room check-in. 97 percent of guests liked the concept of Guest Satisfaction Tracking System. 99 percent of guests appreciated the upcoming installation of check-in \& check-out kiosk in the hotel lobby. 100 percent of guests liked the concept of digital placards for tracking \& locating chauffer at airports. 100 percent of guests liked the process of receiving, greeting $\&$ welcoming them at the hotel main entrance. 98 percent of guests liked the concept of providing recreational activities on Sunday's. 100 percent of guests liked the service of sending chauffer contact details via sms \& e-mail to them well in advance. 100 percent of guests liked the concept of providing minibar in limousines. 100 percent of guests liked the concept of providing welcome drink \& fresh fruits on arrival at the hotel. 100 percent of guests liked the surprise serving of favourite food \& beverage items to their kids on complimentary basis. 100 percent of guests liked the concept of remembering their stays \& providing complimentary dinner \& gift on \& after completing 25 visits. 100 percent of guests mentioned that they would love to visit this hotel everytime they plan to come to Gurgaon city in future based on services \& practices incorporated by front office department.

\section{Conclusion:-}

On the basis of primary \& secondary data collected through various sources in above research study, it is observed that front office department of the The Westin Gurgaon, New Delhi hotel incorporated several innovative practices which have created reasonable positive impact on guest satisfaction levels. Majority of guests mentioned that they will be repeat guests to the hotels \& are fully satisfied \& convinced with services \& practices formulated, incorporated \& implemented by front office department of the hotel.

\section{References:-}

1. Mine Haktanir, Peter Harris, (2005) "Performance measurement practice in an independent hotel context: A case study approach", International Journal of Contemporary Hospitality Management, Vol. 17 Issue: 1, pp.3950

2. Abraham Pizam, Taylor Ellis, (1999) "Customer satisfaction and its measurement in hospitality enterprises", International Journal of Contemporary Hospitality Management, Vol. 11 Issue: 7, pp.326-339

3. Peter J. Danaher, Vanessa Haddrell, (1996) "A comparison of question scales used for measuring customer satisfaction", International Journal of Service Industry Management, Vol. 7 Issue: 4, pp.4-26

4. C J Stefanou, C Sarmaniotis, (2003) "CRM and customer-centric knowledge management: an empirical research", Business Process Management Journal, Vol. 9 Issue: 5, pp.617-634

5. S Brignall, J Ballantine, (1996) "Performance measurement in service businesses revisited", International Journal of Service Industry Management, Vol. 7 Issue: 1, pp.6-31

6. L G Zomerdigk, Jan de Vries, (2007) "Structuring front office and back office work in service delivery systems: An empirical study of three design decisions", International Journal of Operations \& Production Management, Vol. 27 Issue: 1, pp.108-131

7. Michael D. Hartline, James G. Maxham III, Daryl O. McKee (2000) Corridors of Influence in the Dissemination of Customer-Oriented Strategy to Customer Contact Service Employees. Journal of Marketing: April 2000, Vol. 64, No. 2, pp. 35-50.

8. Hokey Min, Hyesung Min, (1997) "Benchmarking the quality of hotel services: managerial perspectives", International Journal of Quality \& Reliability Management, Vol. 14 Issue: 6, pp.582-597 